
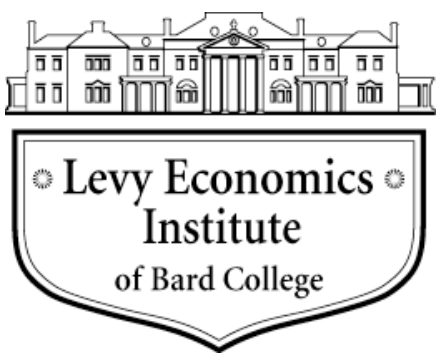

Working Paper No. 759

\title{
Wages, Exchange Rates, and the Great Inflation Moderation: A Post-Keynesian View
}

by

\author{
Nathan Perry \\ Colorado Mesa University \\ Nathaniel Cline \\ University of Redlands
}

March 2013

The Levy Economics Institute Working Paper Collection presents research in progress by Levy Institute scholars and conference participants. The purpose of the series is to disseminate ideas to and elicit comments from academics and professionals.

Levy Economics Institute of Bard College, founded in 1986, is a nonprofit, nonpartisan, independently funded research organization devoted to public service. Through scholarship and economic research it generates viable, effective public policy responses to important economic problems that profoundly affect the quality of life in the United States and abroad.

\author{
Levy Economics Institute \\ P.O. Box 5000 \\ Annandale-on-Hudson, NY 12504-5000 \\ http://www.levyinstitute.org
}

Copyright (C) Levy Economics Institute 2013 All rights reserved

ISSN 1547-366X 


\begin{abstract}
Several explanations of the "great inflation moderation" (1982-2006) have been put forth, the most popular being that inflation was tamed due to good monetary policy, good luck (exogenous shocks such as oil prices), or structural changes such as inventory management techniques. Drawing from Post-Keynesian and structuralist theories of inflation, this paper uses a vector autoregression with a Post-Keynesian identification strategy to show that the decline in the inflation rate and inflation volatility was due primarily to (1) wage declines and (2) falling import prices caused by international competition and exchange rate effects. The paper uses a graphical analysis, impulse response functions, and variance decompositions to support the argument that the decline in inflation has in fact been a "wage and import price moderation," brought about by declining union membership and international competition. Exchange rate effects have lowered inflation through cheaper import and oil prices, and have indirectly affected wages through strong dollar policy, which has lowered manufacturing wages due to increased competition. A "Taylor rule" differential variable was also used to test the "good policy" hypothesis. The results show that the Taylor rule differential has a smaller effect on inflation, controlling for other factors.
\end{abstract}

Keywords: Inflation; Taylor Rule; Post-Keynesian; Structuralist

\author{
JEL Classifications: E12, E31
}




\section{INTRODUCTION}

As inflation and output volatility declined after the 1970s, it became fashionable to declare an end to macroeconomic history. Lucas (2003) famously argued that the problems of "depressionprevention" had been solved by efficient policy. History, however, has returned with a vengeance. As economists look backward for explanations of the present recession, the stylized facts of the so-called "Great Moderation" take on a new importance. In particular, the dangerous deflation and disinflation that followed 2008 and the severe collapse in output and employment call into question the mainstream understanding of the relationships between macroeconomic structure, shocks, and policymaking during the Great Moderation.

The supposed end of macroeconomic history was associated with theoretical and practical developments in the conduct of monetary policy. After the inflationary episode of the 1970s, economists became convinced that central banking was best done independently from democratic politics. Central banks across the world and in developing countries, in particular, were encouraged to declare their independence and adopt technocratic policy rules that would provide credibility, stabilizing market expectations (Grabel 2003). The Great Moderation then was evidence of the success of these institutions.

Prior to 2008, in the midst of the moderation, many heterodox and Post-Keynesian authors argued that stability was hiding structural imbalances that suggested an unsustainable aggregate demand regime. ${ }^{1}$ In addition, some, following a Minskyian (1986) line, argued that the moderation itself was partly responsible for the crisis, by encouraging greater leveraging (Keen 2013). Thus, household balance sheets and fragile financial structures have been at the center of heterodox and Post-Keynesian descriptions of the crisis. In this view, central bank independence and rigid policy rules bear no direct responsibility for stability, and in fact may be detrimental (Arestis and Sawyer 2008).

The stability in inflation that supposedly resulted from the new policy framework can, however, be explained along Post-Keynesian and structuralist lines. While the consensus among mainstream macroeconomists suggests that the rate of inflation is a monetary phenomenon, the level of inflation in Post-Keynesian thought has traditionally been related to distributional conflict (Lavoie 1992). Thus, Post-Keynesian pricing models tend to emphasize cost pressures

\footnotetext{
${ }^{1}$ Among others, Godley (1999), Palley (2002), and Keen (2006). Bezemer (2009) discusses a selection of economists - many in the heterodox/Post-Keynesian camp, who predicted a debt deflation style crisis.
} 
and would look to wage demands, commodity prices, import prices, and markups to explain the Great Moderation in inflation.

This paper seeks to test the relevance of cost factors as opposed to changes in monetary policy during the period of inflation moderation. Using a vector autoregression (VAR) analysis, we test the contribution of wage pressures and exchange rate pass through as compared to the "good policy" hypothesis of some mainstream authors as represented by a Taylor rule differential. In addition, a competing hypothesis in the mainstream literature suggests that "good luck," potentially in the form of fewer oil shocks, may have meant that policy had an easier task during the Great Moderation. We suggest that oil prices may actually be endogenous to the system through exchange rate effects. Our results confirm the importance of cost pressures and their interaction, and deemphasize the role of policy rules.

The paper proceeds as follows: Section 2 provides a short summary of the basic features of the Great Moderation and the new consensus macroeconomics that emerged during this period. Section 3 discusses the Post-Keynesian and structuralist view of inflation. Section 4 provides the details of the data and the importance of the relationships between variables that make this study unique. Sections 5 and 6 provide the model and results for a vector autoregression with an explicitly Post-Keynesian ordering that tests for both cost push and "good policy" factors. Section 7 concludes with suggestions for further exploration.

\section{THE INFLATION MODERATION AND THE NEW CONSENSUS MACROECONOMICS}

Most authors have dated the decline in price volatility to the early 1980s (see, for example, Stock and Watson 2003). This is confirmed in Table 1, which presents the standard deviations for compensation, output, unit labor costs, crude materials inflation, and consumer price index (CPI) inflation for the post-WWII period. Notably, volatility in CPI inflation was more than halved. Similarly, smaller declines in volatility can be seen in hourly compensation, output per hour, and unit labor costs. Interestingly, crude materials have actually increased in volatility, a feature in line with the commodities price boom of the 2000s, which followed nearly two decades of relative depressed prices. 
Table 1 Volatility of wage, productivity, and unit labor costs 1948-2006

\begin{tabular}{lcccc}
\hline & Compensation* & Output per Hour* & Unit Labor Cost* & Crude Materials Inflation \\
\hline 1948-2006 & 0.0073 & 0.0088 & 0.0111 & 0.0418 \\
$1948-83$ & 0.0072 & 0.0100 & 0.0124 & 0.0331 \\
1984-2006 & 0.0064 & 0.0065 & 0.0081 & 0.0528 \\
Relative S.D. & 0.8965 & 0.6504 & 0.6563 & 1.5915 \\
\hline
\end{tabular}

* Indicates variables in growth rates.

One can see the decline in the volatility of prices in Figure 1, which plots the rolling standard deviation of CPI inflation with a 20-quarter window. Here, the decline in volatility seems less abrupt than implied by the 1983 break date in Table 1. Indeed, a point of contention among macroeconomists has been whether to view the Great Moderation as a stark break, with some arguing that it should rather be seen as a declining trend in volatility (Blanchard and Simon 2001).

Figure 1 20-Quarter rolling standard deviation of CPI inflation

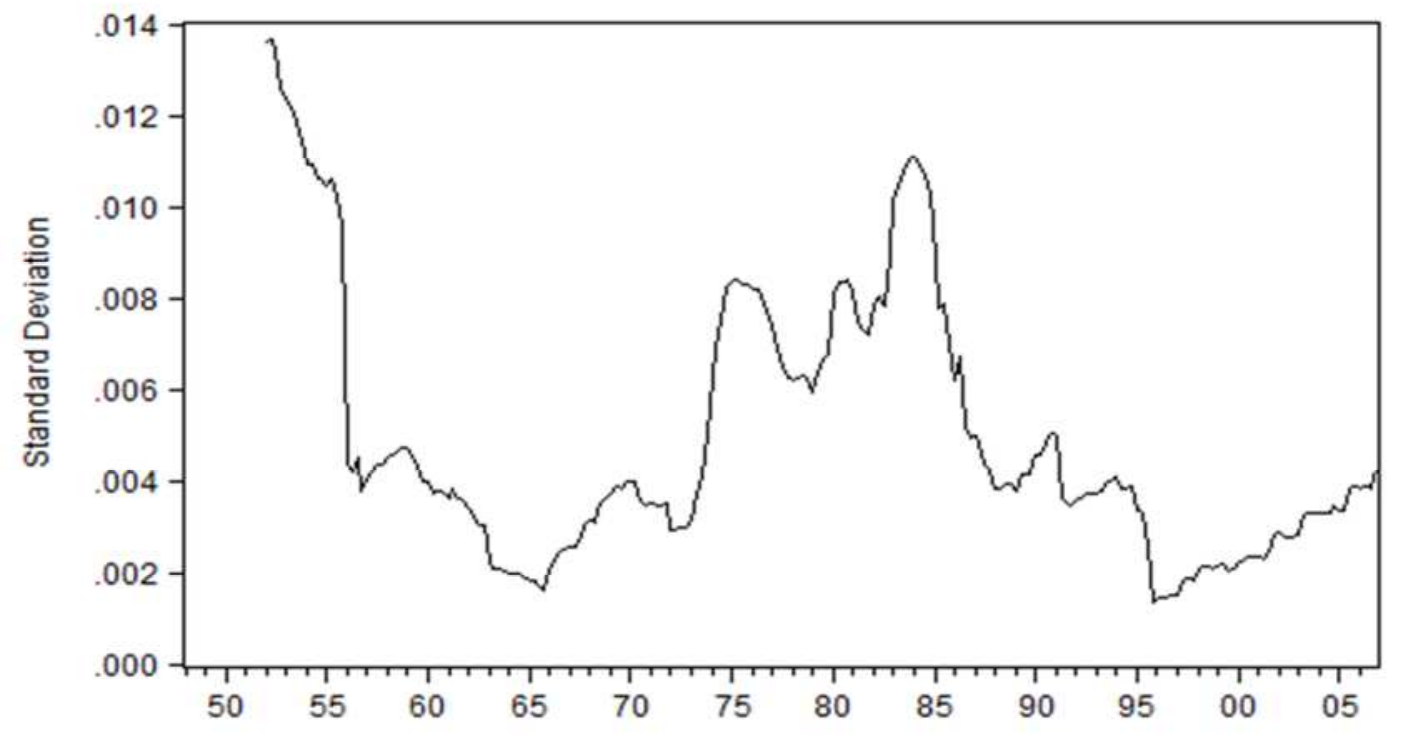

What is clear, however, is that after a particularly volatile period in the 1970s, inflation levels and volatility declined steadily until at least the mid-2000s. This was roughly coincident with the decline in the volatility of other macroeconomic series, including output growth (Kim, 
Nelson, and Piger 2003). The debate has thus focused on the causes of the moderation of macroeconomic data.

In general, explanations have been grouped into three camps: good policy, good luck, and structural changes. Good policy reflects the introduction of macroeconomic rules, particularly central bank policy rules, which were supposed to bring transparency and credibility, which would in turn moderate inflation and output. Good luck reflects a host of factors domestic and international, including but not limited to financial market shocks, commodity price shocks, and technology shocks. The structural change explanations have concentrated on information technology and other changes that make inventory management easier and less prone to mistakes.

A common thread amongst mainstream treatments of decline in inflation and its volatility is the firm belief that ultimately inflation is a monetary phenomenon. In this sense, no matter the specific causes, in the long run inflation is always and everywhere a result of money supply expansion. That is, without an accommodating monetary policy, persistent inflation is not possible. The implication is thus that inflation has its origins in excess demand.

The method by which monetary changes affect prices has, since Friedman (1968), operated through an output (or unemployment) and inflation tradeoff. Behind these models lie the "natural" rates of interest and unemployment. As in Wicksell (1898), when the market rate of interest is equal to the natural rate, inflation will be constant, output will be at capacity, and unemployment at its natural level.

The traditional Phillips curve was challenged in the 1970s when the economy experienced both low unemployment and inflation. It was then argued by monetarists that the Phillips curve's tradeoff was a short run phenomenon (Friedman 1968). In the short run, monetary policy can produce output as well as inflation changes, but in the long run, monetary policy simply influences prices. ${ }^{2}$ The natural rate of unemployment will emerge in the long run as expectations of inflation catch up to actual inflation. The only way to maintain unemployment below the natural rate, then, is to continually accelerate inflation.

In the longer run, a tradeoff between output and inflation should not exist as output is restored to its potential level. However, a tradeoff between the volatility of output and inflation may indeed exist in "New Consensus" models as argued by Taylor (1979). Though in levels, the

\footnotetext{
${ }^{2}$ The short run tradeoff results from a host of imperfections—-for instance, Lucas's (1972) signal extraction problem.
} 
tradeoff disappears, in terms of volatility, policymakers can choose the extent to which they respond to short run deviations of output and inflation. Essentially, as short run shocks cause deviations to the level of inflation or output, the monetary authority chooses the extent to which it wishes to push inflation and output back to their natural levels. If inflation is persistent, this may mean the authority will have to overreact (Chatterjee 2002). The monetary authority is thus not attempting to maintain permanently higher (lower) output or inflation, but instead to offset short run shocks. The required overreaction, however, means that either output or unemployment will increase in variability. This generates a long run Taylor curve in which the central bank can choose between decreased volatility in output or inflation. Taylor's (1993) famous "rule" suggests that central banks respond to inflation and output gaps with equal weight.

The basic "new consensus macroeconomics" (NCM) that emerged from the experience of the 1970s includes a version of the basic monetary policy rule. ${ }^{3}$ The NCM model can be described in three basic equations (for instance, Arestis and Sawyer 2004; Carlin and Soskice 2005; Meyer 2001):

$$
\begin{aligned}
& \text { 1. } y_{t}^{g}=\alpha_{0}+\alpha_{1} y_{t-1}^{g}+\alpha_{2} \xi\left(y_{t+1}^{g}\right)-\alpha_{3}\left[r_{t}-\xi\left(p_{t+1}\right)\right]+\varepsilon_{1} \\
& \text { 2. } p_{t}=\beta_{1} y_{t}^{g}+\beta_{2} p_{t-1}+\beta_{3} \xi\left(p_{t+1}\right)+\varepsilon_{2} \\
& \text { 3. } r_{t}-r^{*}=p_{t}+\gamma_{1}\left(p_{t-1}-p^{*}\right)+\gamma_{2} y_{t-1}^{g}
\end{aligned}
$$

In the above, $\mathrm{y}^{\mathrm{g}}$ reflects the output gap, $\mathrm{r}$ is the nominal interest rate, and $\mathrm{p}$ is the rate of inflation. Asterisks indicate the target or natural rates, $\xi$ indicates expectations of a particular variable, and the usual time subscript. Equation 1 suggests that output is a function of the past and expected future output gap, as well as the expected real rate of interest. Equation 2 is a standard expectations augmented Phillips curve. Finally, Equation 3 is a central bank policy rule.

The obvious implication of the NCM model described above is to promote fiscally "responsible" governments and independent central banks. A credible and independent central bank should thus be able to avoid the famous problem of time inconsistency. With the public no longer suspicious that central banks will renege on their policy announcements, the tradeoff between output and inflation should be reduced. By simply committing to clear and consistent rules, central banks can make the pain of inflation stabilization substantially less.

\footnotetext{
${ }^{3}$ A description and critique of NCM can be found in Arestis and Sawyer (2004).
} 
In this framework however, a decline in inflation and output volatility simultaneously cannot be the result of a new mix of policy preferences. As Bernanke (2004) argues, the coincident decline in volatility could be because prior to the Great Moderation, policy operated to the left of the Taylor curve. Thus, better policy would be able to move rightward onto the curve. Alternatively, the curve itself could shift to the right as a result of a structural change in the economy. A final cause of the decline in volatility could be the reduction in shocks that the central bank must respond to- $-\mathrm{a}$ view that Bernanke believes cannot explain sustained declines in volatility. The literature on the causes of the Great Moderation can thus be conveniently separated into three basic causes: good policy, good luck, and structural change.

Explanations that rely on "good policy," then, suggest that the economy prior to the 1980s was operating outside of the Taylor curve. Romer and Romer (2002), in particular, emphasize that large shifts in economic policy occurred in the 1970s as a result of changes in the prevailing opinion of economists and policymakers. In their telling, prior to the VolkerGreenspan era, the Federal Reserve essentially believed that little could be done about inflation, which was primarily a cost issue. Additionally, they were working under an assumed "natural rate" of unemployment far below what Romer and Romer (2002) suggest could have been the case. Clarida, Gali, and Gertler (2000) confirm the Romer and Romer (2002) narrative by estimating a monetary policy rule before and after Volker. They conclude that the Federal Reserve did not prioritize inflation in interest rate decisions and thus let the real interest rate fall in times of inflation. What was lacking, according to Meltzer (2005) was a common theory of money and monetary policy among participants in the open market committee. Taylor (1999) himself agrees and suggests that without a clear policy rule, monetary policy was marked by "policy mistakes" prior to the Great Moderation. ${ }^{4}$

In this telling then, the central bank was not credibly committed to fighting inflation. In fact, several authors have argued that oil shocks could not be the primary cause of the inflationary period of the 1970s, as sustained inflation would not have been possible without accommodating monetary policy (see, for instance, DeLong 1997). Thus, while there may have been cost effects, ultimately the inflation, and its costly reduction, was due to the lack of credible policy rules by the Federal Reserve. Stable inflation, in turn, should lead to stable output.

\footnotetext{
${ }^{4}$ Taylor (2012) notably believes that the Federal Reserve abandoned sensible rules in favor of discretion by 2003.
} 
Explanations that focus on "luck" typically emphasize the decline in shocks (as opposed to propagation mechanisms). Stock and Watson (2003) use a structural vector autoregression (SVAR) to investigate the role of output shocks internationally. Though they are unsure what shocks matter, they emphasize that changes in propagation cannot explain the full decline in volatility. Ahmed, Levin, and Wilson (2004) find similar declines in shocks, with a similar lack of identification of particular shocks. Justiniano and Primiceri (2006) are more explicit and suggest a reduction in "investment specific technology shocks." In their view, these are the result of a decline in financial friction (and thus better capital allocation). Proponents of the "good luck" hypothesis thus tend to focus on unforecastable disturbances in VAR models, but in general are not specific about what shocks are declining. While some popular varieties of the good luck hypothesis focus on oil price shocks (Hamilton and Herrera 2004), we will suggest in the following section that these shocks may actually be endogenous to monetary policy.

A final category of explanation is the structural change hypothesis. Most often, the structural change hypothesis has focused on inventory management. McConnell and PerezQuiros (2000) suggest that a decline in GDP volatility can be traced to a decline in the share of inventories in durable goods production. This explains the observed decline in the volatility of durable goods production, while the volatility of durable goods sales has remained stable. Kahn, McConnell, and Perez-Quiros (2002) have argued that greater information has made predicting demand patterns easier, and thus inventory-to-sales ratios have declined. In general, then, one could argue that the structural change may have affected the slope of Phillips and Taylor curves.

\section{POST-KEYNESIAN INFLATION}

The improved policy hypothesis has perhaps garnered the most attention, particularly among central bankers. The difficulty with this story is that while the Federal Reserve may have prioritized inflation with the arrival of Volker, it isn't clear that independent, rule-bound central banks actually do result in better inflationary experiences. Inflation targeting and independent central banks may actually have come on the "heels of a decade of low inflation," as Dueker and Fischer (2006) put it. That is, in the context of already declining inflation, it is hard to isolate a major influence of inflation targeting rules. This is in line with broader evidence that interest rates have little influence on the rate of inflation, as argued by Arestis and Sawyer (2004), and 
that a output-inflation volatility tradeoff has questionable empirical support (Arestis, Caporale, Cipollini 2002).

The Post-Keynesian models of inflation do not rely on natural rates as in the NCM model. Indeed, as Galbraith (1997) argues, the notion that there is a rate of unemployment (or output) beyond which inflation is accelerating, suffers from both theoretical and empirical problems. In addition, following Keynes (1936), the Post-Keynesian macroeconomic vision rejects the concept of a Wicksellian natural rate of interest. Instead, cost push inflation is emphasized, which in turn is often related to distributional conflict. At the microeconomic level, Post-Keynesian pricing models all rely in some form or another on cost plus pricing. In addition, in these models money is typically endogenous (Smithin 2003). The rate of unemployment or activity may thus influence wage demands or commodity prices, but in general Post-Keynesians reject any unambiguous relation between these variables and the rate of inflation.

Inflation, then, is often the result of inconsistent claims on output, as wages exert the main pressure on costs. Though some heterodox models endogenize wage demands, wages are often considered to have a strongly exogenous element that is historical and dependent on bargaining conditions. ${ }^{5}$ To the extent these wage demands grow faster than labor productivity, firms have the choice to either reduce costing margins, or attempt to pass on these costs into prices. ${ }^{6}$ In addition, as structuralist authors emphasize, cost pressures can come from commodity price shocks and exchange rate depreciation, the effects of which are then resisted by labor. ${ }^{7}$

Thus, rather than poor monetary policy, Post-Keynesians focus on cost factors to explain the rising inflation of the 1970s. Supply side shocks, when passed on in prices, resulted in wage pressures as workers' bargaining power was comparatively strong in the Golden Age policy regime. The inflation subsided, not as a result of "good policy" but a decline in the labor movement.

We can then construct a simple Post-Keynesian and structuralist model of inflation, comparable to the basic Phillips curve of Equation 2 in the previous section:

$$
\text { 4. } p_{t}=\delta_{0}+\delta_{1} \omega_{t}+\delta_{2} p_{t}^{c}+\delta_{3} e_{t}+\delta_{4} p_{t-1}
$$

\footnotetext{
${ }^{5}$ See Taylor (2004) for models that relate the wage to capacity utilization.

${ }^{6}$ Thus, wages are considered to be determined by the political economy of wage bargaining, not by marginal productivities.

${ }^{7}$ See for instance the description of inflation in Sunkel (1958) and Furtado (1959)
} 
In the above, $\omega$ reflects the growth of unit labor costs (wage growth minus productivity growth), the superscript c indicates commodity prices, and e reflects the growth of import prices in domestic currency. Thus inflation is the result of cost pressures coming from wages, commodity prices, the real exchange rate, and wage resistance to past inflation $\left(\mathrm{p}_{\mathrm{t}-1}\right)$, where $\delta_{0}$ can be interpreted as the markup. A moderation in volatility must then be related to moderations in volatility in the costs of production. In the following section we discuss the data used to measure unit labor costs, commodity prices (in this case oil), and exchange rates. We then build a VAR model to test the basic Post-Keynesian markup model as compared to the good policy hypothesis.

\section{THE DATA}

The data sources are listed in Table 2.

Table 2 Data sources

\begin{tabular}{|c|c|c|}
\hline Variable & Details & Source \\
\hline Federal Funds Rate & & $\begin{array}{l}\text { Federal Reserve Bank of St. } \\
\text { Louis (FRED) }\end{array}$ \\
\hline Real GDP & & $\begin{array}{l}\text { International Monetary } \\
\text { Fund, International } \\
\text { Financial Statistics (IMF IFS) }\end{array}$ \\
\hline CPI & & IMF IFS \\
\hline Manufacturing Wages & & IMF IFS \\
\hline Oil Prices & $\begin{array}{l}\text { Spot Price West Texas } \\
\text { Intermediate }\end{array}$ & FRED \\
\hline Nominal Exchange Rate & $\begin{array}{l}\text { Weighted by largest trading } \\
\text { partners }\end{array}$ & FRED \\
\hline Taylor Rule Differential & & $\begin{array}{l}\text { Author Calculated, raw data } \\
\text { from FRED }\end{array}$ \\
\hline Import Prices & & IMF IFS \\
\hline Potential GDP & & FRED \\
\hline GDP Deflator & & FRED \\
\hline Unit Labor Costs & & BLS.gov \\
\hline Unionization Rate & $\begin{array}{l}\text { Percentage of Total } \\
\text { Employment }\end{array}$ & BLS.gov \\
\hline
\end{tabular}




\section{Taylor Rule Differential}

The Taylor rule, derived from Equation 3 above, is calculated as follows:

$$
\text { 5. } r_{t}=p_{t}+r^{*}+\gamma_{1}\left(p_{t-1}-p^{*}\right)+\gamma_{2} y_{t-1}^{g}
$$

Following Taylor (1993), the coefficients on inflation and the output gap are assumed to be weighted each at .5 , illustrating a dual mandate between inflation and unemployment. The equilibrium federal funds rate is assumed to be 2 percent, the inflation target 2 percent, while the inflationary expectations is calculated as the average of the previous four quarters of inflation. ${ }^{8}$ The deviation from the Taylor rule is then calculated as the difference between the predicted Taylor Rule and the actual Federal Funds rate. This variable will be a test of whether "good policy" has had a legitimate effect on curbing inflation and its volatility. If good policy is the reason for lower inflation and lower inflation volatility, then as the Taylor rule deviation gets higher, inflation will increase. If good policy is important, then the impulse response functions will show that a positive shock to the Taylor rule will cause inflation to rise. The Taylor rule differential was devised for this test because the Taylor rule is the best representation of "good policy" that can be quantified. The Taylor rule also represents the majority view of economists as to how to conduct monetary policy. The authors have not found another paper that uses a Taylor rule differential to test the good policy hypothesis, so we consider it unique to the literature.

Figure 2 shows the relationship between the Taylor rule and the Federal Funds rate, with the Taylor rule generally higher than the Federal Funds rate for the 30 years of data. Figure 3 shows the relationship between the Taylor rule differential and the inflation rate. Visually, there is a strong relationship in the 1980s between the Taylor rule differential and the inflation rate. As the differential gets high, inflation gets higher. The strong relationship in Figure 3 does not necessarily imply causality. They may each be following a trend caused by a third variable or other economic factors.

\footnotetext{
${ }^{8}$ The GDP deflator was used for the measure of inflation in the inflation gap, while CPI was used to measure inflation expectations since consumers react to announcements in CPI rather than the GDP deflator.
} 
Figure 2 Taylor rule differential and Fed Funds rate

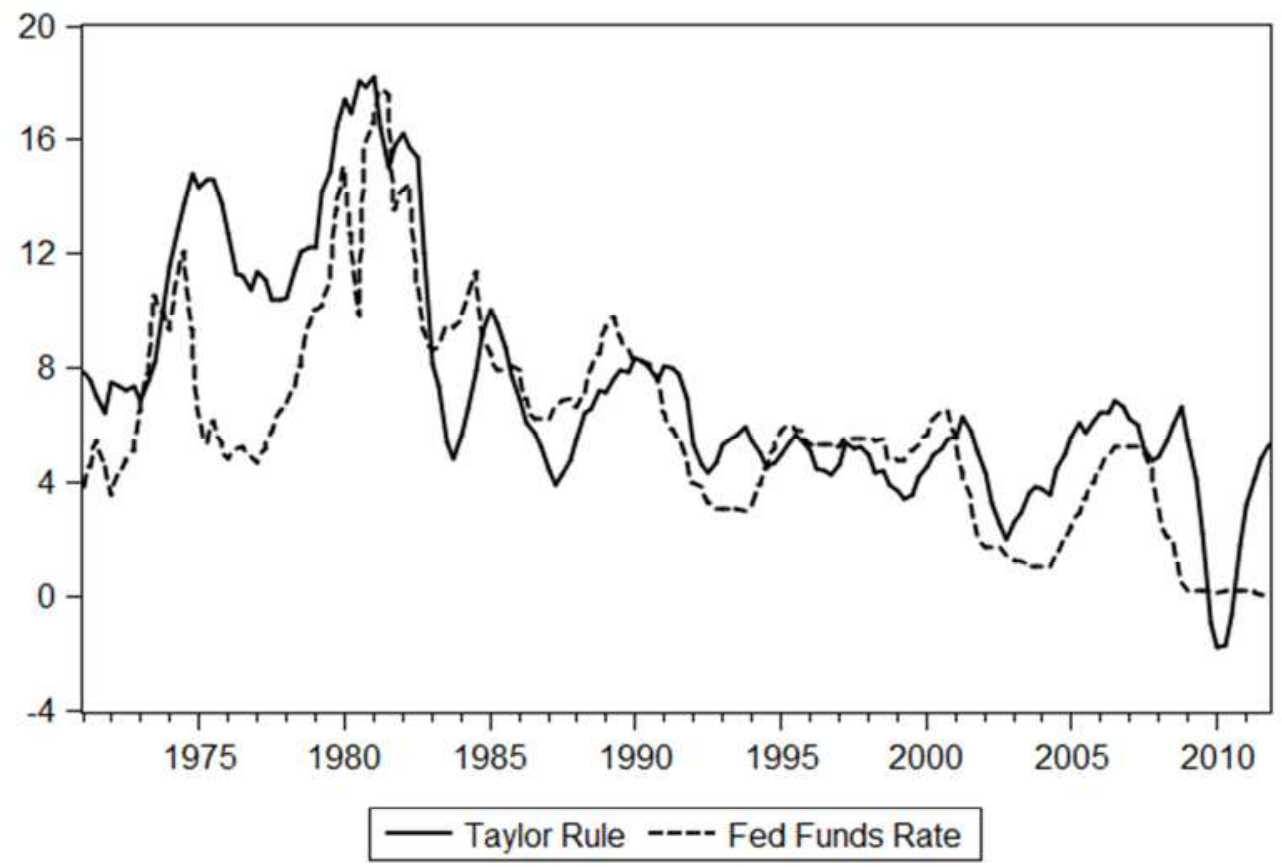

Figure 3 Taylor rule differential and inflation

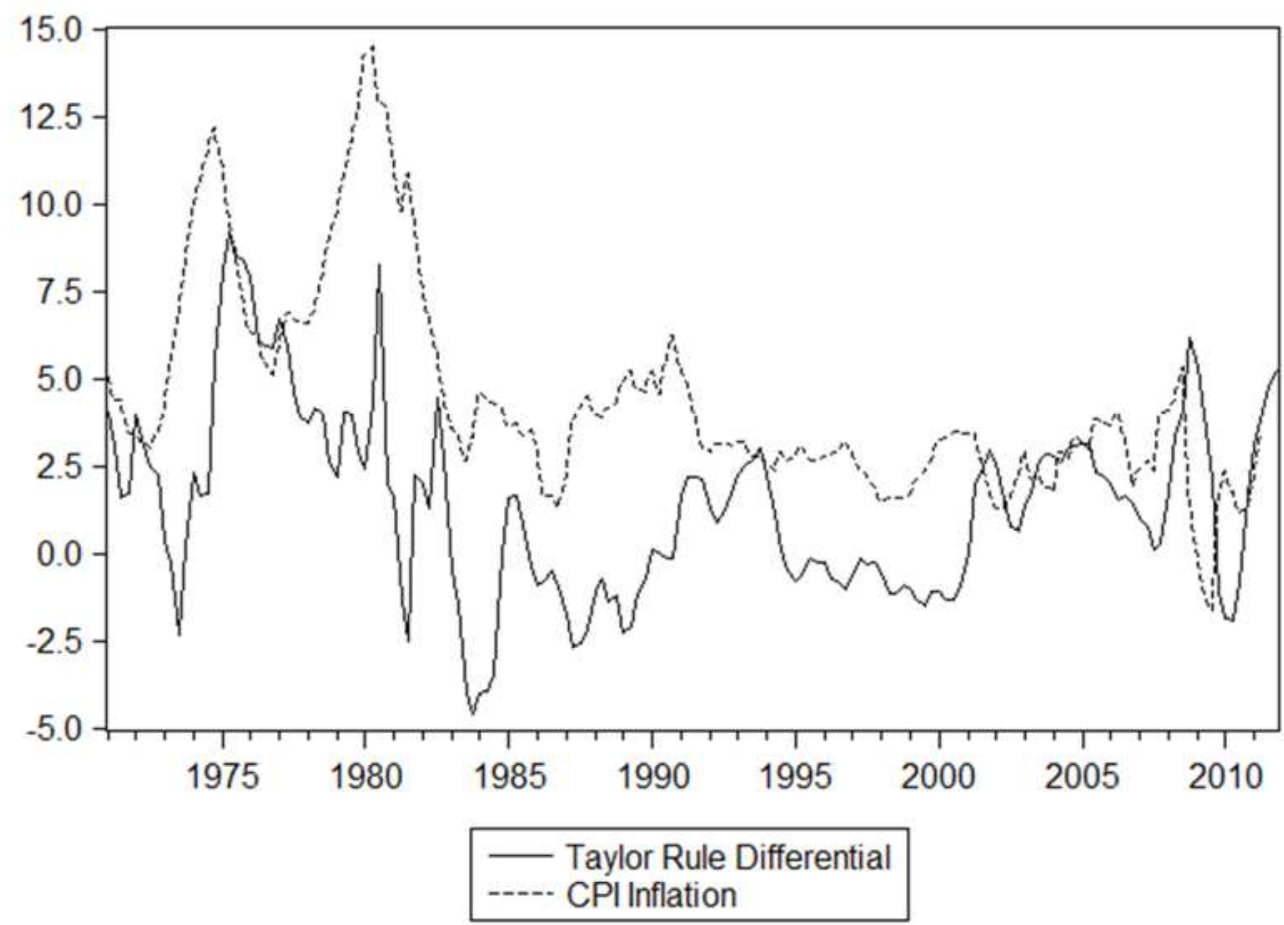




\section{Wages}

Unit labor costs from the Bureau of Labor Statistics are used as the primary measure of wages. ${ }^{9}$ This accurately reflects the costs to business that would affect prices in a markup model. Figure 4 shows a distinct drop in wages that begins in 1980 and maintains itself until wage volatility increases near 2006. The drop in wages coincides almost perfectly with the decline in the inflation rate and inflation volatility. There are several explanations for the fall in real wages during this time period. The first is the loss of collective bargaining and declining union membership as shown in Figure 5. There is a distinct drop in union membership at the same time (1980-1982) as the fall in inflation and wages. This occurs at the same time as productivity breaks away from compensation (Figure 6), and workers stop receiving pay increases to keep up with productivity.

Figure 4 Growth of unit labor costs

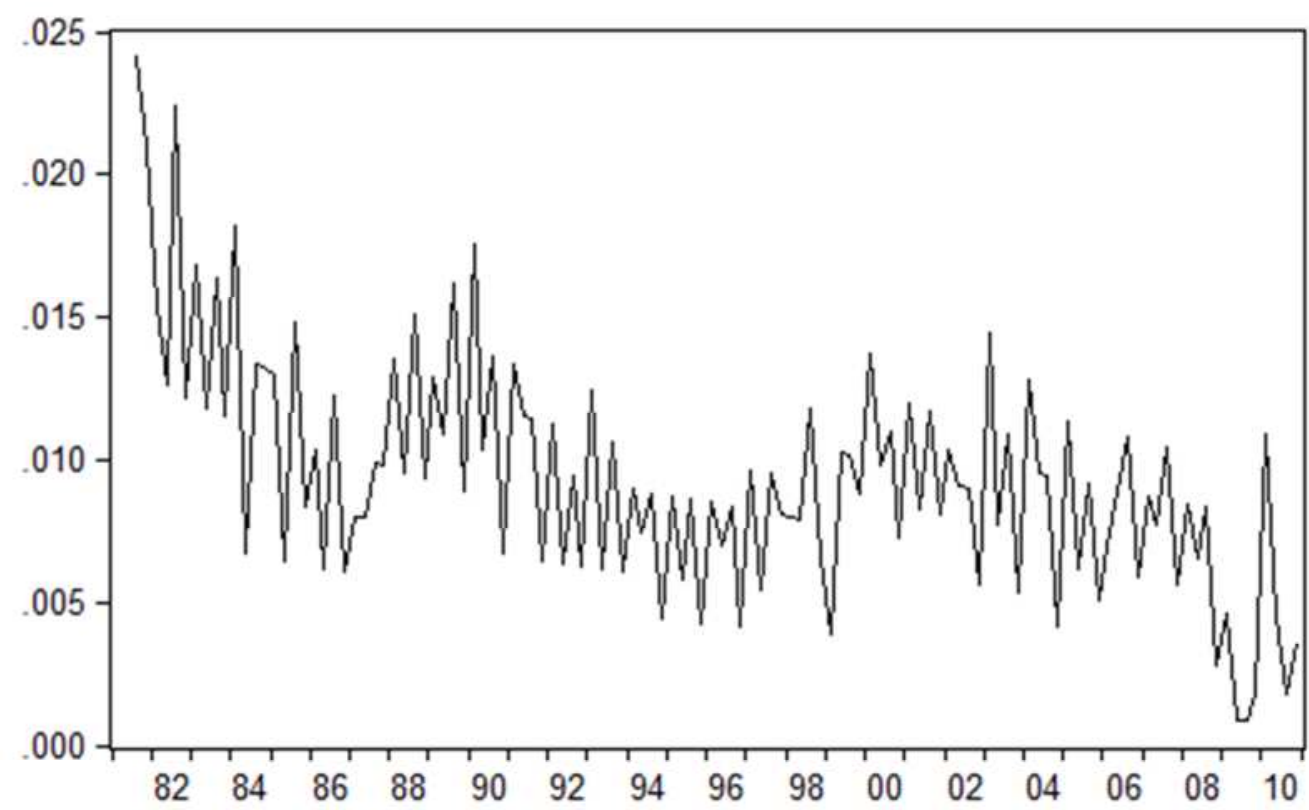

\footnotetext{
${ }^{9}$ Other measures of wages were used including manufacturing wages (IMF IFS) and showed almost identical results in the model.
} 
Figure 5 Union membership as a percentage of labor force

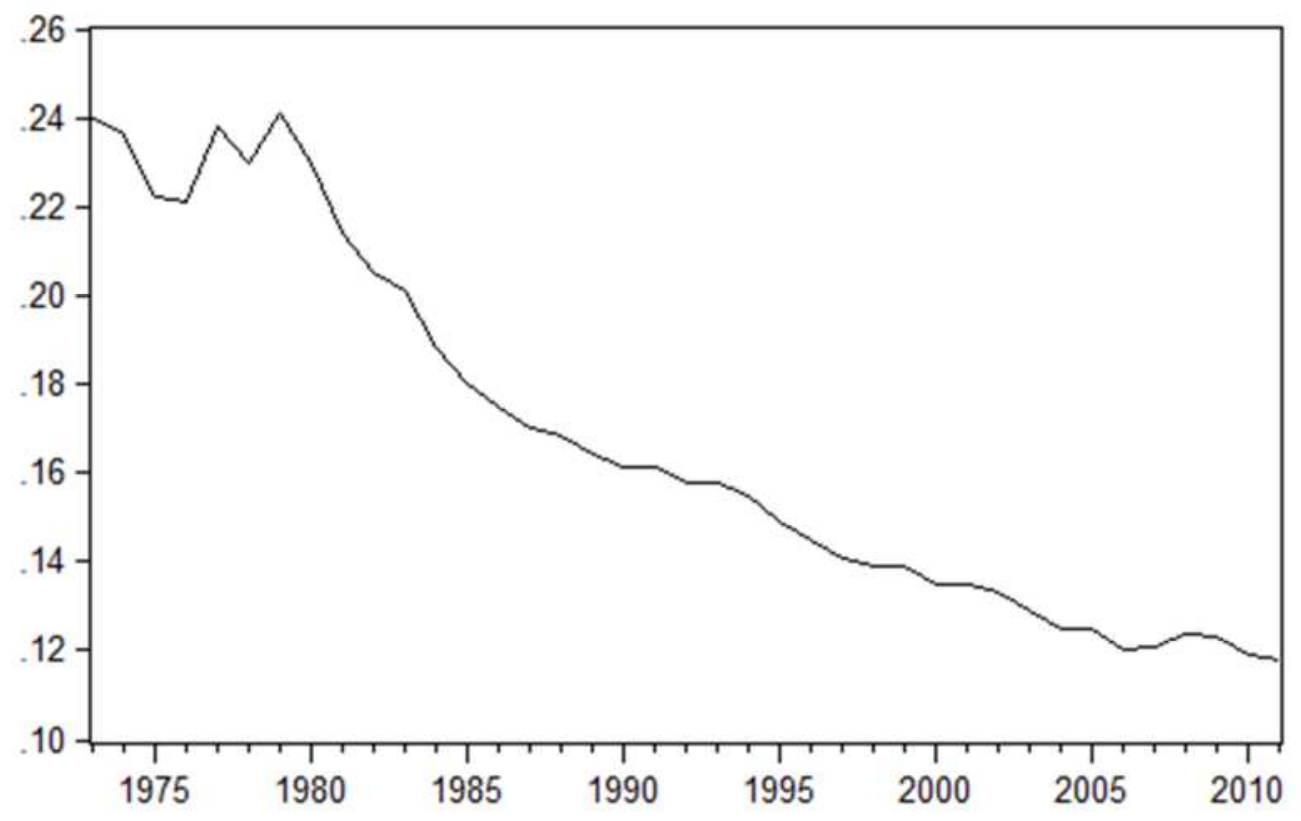

A second factor in the decline of US wages may be increased international competition. Businesses relocate to areas with cheaper manufacturing costs and US workers are forced to take lower wages to compete for manufacturing. There is an exchange rate aspect to this story, as well. Because the US holds the hegemonic currency, demand for dollars and treasury bonds is always very high. This increases the value of the dollar beyond what it would be if the US were not the global hegemon. High interest rates in the 1980s and high growth in the 1990s, and a booming stock market relative to world growth and world stock markets kept demand for dollars high, which appreciated the US dollar. This appreciated dollar made it difficult for exporting businesses to compete. Not only were costs cheaper in other countries in the global economy, but exchange rate effects accelerated the losses to US manufacturing, eventually leading to lower wages. 
Figure 6 Productivity and compensation

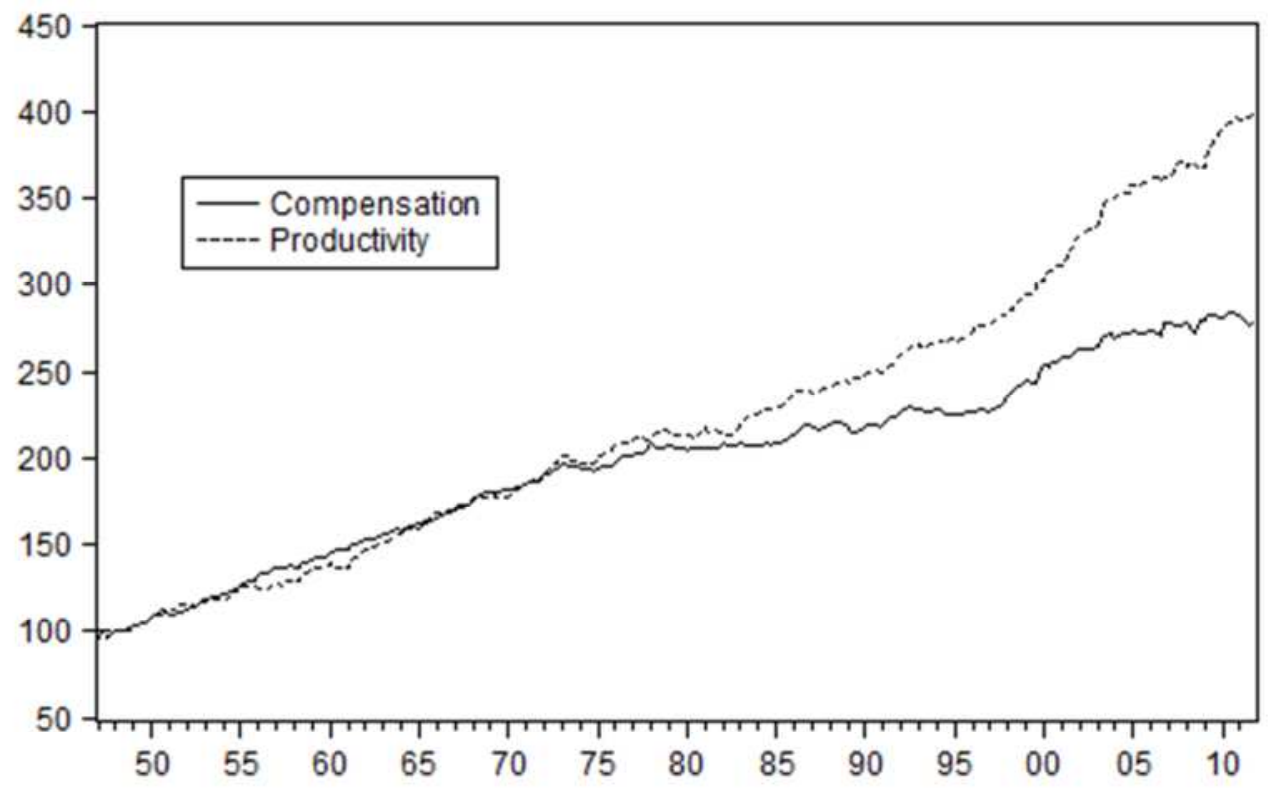

In terms of productivity, neoclassical theory argues that the difference between productivity and wages is the marginal productivity of capital, or technology. Wages are paid according to their marginal productivity of labor, so if wages fall and productivity rises, it must be that capital is driving productivity. This same explanation can be given to justify the large disparity in income distribution during the same time period. This paper takes the point of view that wages are not automatically paid the marginal productivity of labor, but are paid in accordance with their bargaining or political power. Workers are no longer being compensated for their productivity at the same level they were during the previous 30 years, which has reduced wages costs and therefore inflation. Aside from Reagan era anti-union policies, high interest rates and an overvalued exchange rate helped reduce exports and increase the volume of ever cheaper imports, reducing wages especially in the manufacturing sector, which had a high unionization rate and high wages. The empirical model will attempt to shed light on this as well as disseminate the effects in this highly endogenous system.

\section{Exchange Rates and Import Prices}

Neoclassical theory focuses on exchange rate determination as derived from purchasing power parity. In the long run, exchange rates are merely a function of two countries' inflation rates, 
and the exchange rate adjusts for the two countries' inflation rates. Post-Keynesians emphasize the role of exchange rates on inflation by means of pass-through effects and cheaper import prices. The chain of causality is as follows: The Federal Reserve increases interest rates, exchange rates climb because of the increase in demand for treasury bonds, which skyrocket in uniform with the Federal Funds rate. As exchange rates increase, the price of imports falls. American consumers purchase more foreign goods, which eliminates American companies' profits in manufacturing. As prices fall in the manufacturing sector, wages are cut. Inflation then falls in response to this chain of events. The exchange rate is not a passive adjustment mechanism between two countries; it can be a means of inflation transmission due to domestic and international policy. The nominal trade weighted exchange rate for the US dollar against its primary trading partners was used. ${ }^{10}$ The nominal exchange rate is used to capture the passthrough effects of exchange rates to import prices, commodities, and then to inflation.

\section{THE EMPIRICAL MODEL}

The empirical model is set up to test the causal factors and their contributions to the changes in inflation. The model does not test inflation volatility directly. The idea is that if you can determine the causal factors of inflation, then you can determine the causal factors of the variation in inflation. This is typical in the Great Moderation literature. The empirical model uses a vector autoregression and an identification strategy that follows Post-Keynesian principles in the ordering of the variables. The ordering is important because the contemporaneous innovations for all of the variables on the left-hand side will impact all the other variables on the right-hand side, whereas the variables ordered last will not have a contemporaneous effect on the left side variables.

The Taylor rule differential will tell us if inflation or disinflation is the consequence of deviating too far from the Taylor rule. Import prices are used to show the effect of low import costs on falling inflation. The primary method by which import prices fall is through a rise in the exchange rate. Oil is included to test the hypothesis that many Great Moderation papers have had, mainly that "exogenous" oil shocks are responsible for lower inflation in the Great Moderation. The order of the variables starts with the Taylor rule differential, since the Federal Reserve controls the short-term interest rate and can choose whether to deviate from the "rule."

\footnotetext{
${ }^{10}$ Data is from the IMF International Financial Statistics (IFS).
} 
Next is the exchange rate, since exchange rate fluctuations are primarily determined by changes in interest rates (Harvey 2006). This is followed by import prices and then oil prices, since both import prices and oil prices are assumed to be affected to some degree by changes in the exchange rate. Wages in part respond to exchange rate changes and the falling import prices that put pressure on domestic workers and labor bargaining. And finally inflation responds to all of these variables contemporaneously. This ordering is in the Post-Keynesian tradition because of three primary reasons:

1) It is assumed that exchange rates are not driven by purchasing power parity, or that inflation is not the only or primary causal factor in exchange rate fluctuations (Harvey 1991). In this model, exchange rate effects can affect inflation first (passthrough effects) before inflation can affect the exchange rate.

2) The role of wages in reducing inflation draws upon two points: The first is that workers are not paid according to their marginal productivity of labor, and are in fact subject to collective bargaining and class conflict. The second is that unionization has declined and wages have been pushed down.

3) The model assumes that money is endogenous. If money supply changes caused inflation to change, money supply would need to be included in this model. Because money is considered endogenous, and it is assumed that the central bank only has control over short-term interest rates and not the money supply, the money supply variable is omitted from the model.

Two important points need to be made. The first is the relationship between oil and exchange rates. Oil is generally assumed to be exogenous because supply decisions are made by the Organization of the Petroleum Exporting Countries (OPEC) or other oil exporting countries. Or, in more severe cases where war decisions threaten global supply, the price shock may be exogenous. However, oil prices can be argued to be endogenous in this system in two ways. The first is that oil output decisions are made with world demand in mind. In other words, oil production decisions take into account the demand of the customers (growth), which makes oil endogenous to the system above. The second way that oil is endogenous is that exchange rate fluctuations can affect the oil production decisions of OPEC. Because the dollar is the international reserve currency, oil and other commodities are sold in dollars which creates a special relationship between commodities and oil. Suppose OPEC has a profit goal of a set markup on oil prices, which are highly inelastic. When OPEC countries sell oil they receive 
dollars, which means in order to spend these dollars they have to be recycled or converted into the domestic currency. When the US dollar is high in value, the price does not have to be as high to adjust for exchange rate effects. When the US dollar is low in value, oil must be priced higher in order to meet the same profit targets. As the financial system has increased in sophistication, hedging and speculating have become an integral part of the oil-dollar relationship. Now when international investors believe the US dollar is going to fall, instead of selling out of their positions to avoid the exchange rate loss, they will buy assets that they believe will go up in value as the dollar falls. A favorite US dollar hedging device on Wall Street is oil, which makes oil highly endogenous in this system. This is apparent in Figure 7.

Figure 7 US dollar index and oil price index

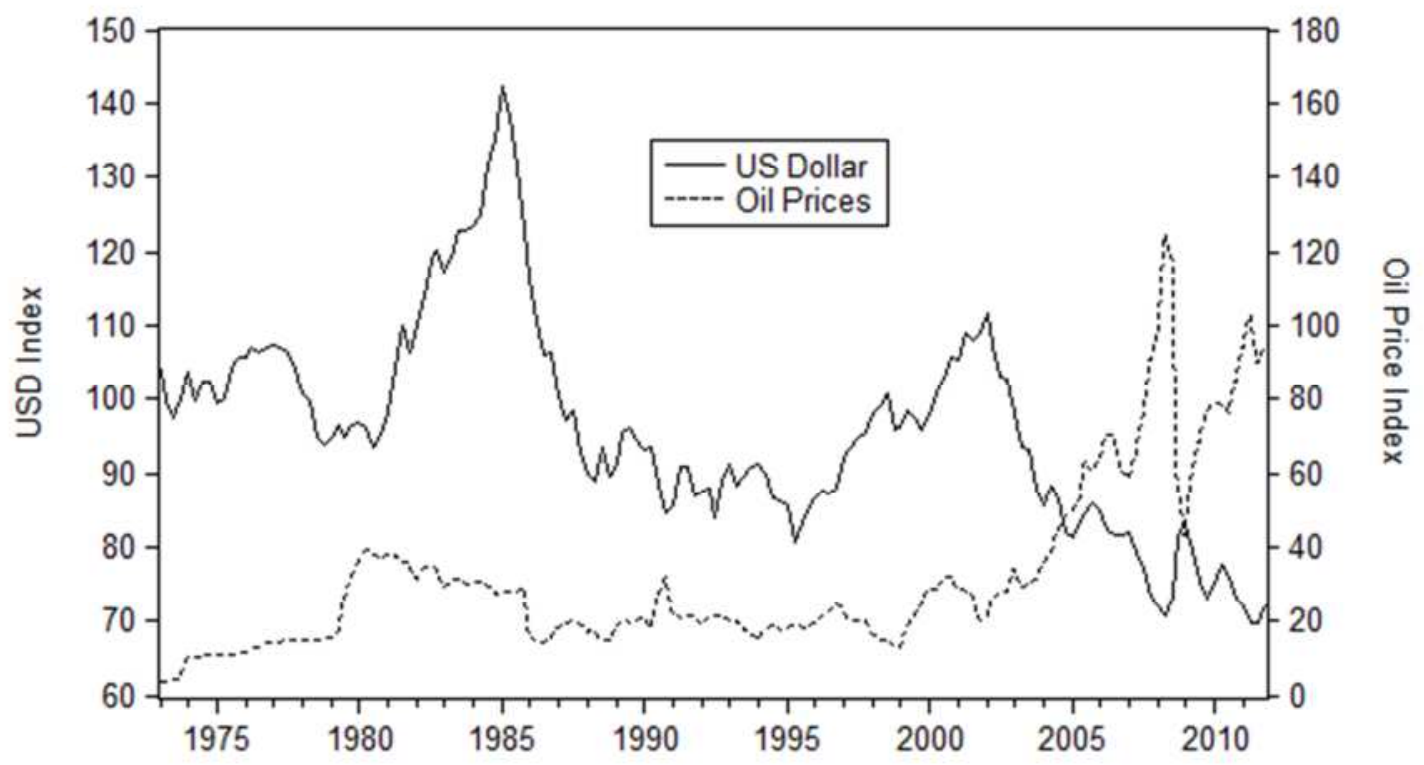

Because of this, oil is listed after the exchange rate. This implies that the innovations of the exchange rate can affect oil contemporaneously, but that oil prices cannot affect the exchange rate contemporaneously.

In contrast, a standard neoclassical model addressing the ordering of the variables to determine the causes of the Great Moderation may look like the following: Money supply would be listed first because the Fed is assumed to control the money supply. Interest rates are determined by the manipulation of the money supply and listed second. Inflation would be third, because inflation is a direct result of changes in the money supply. Since the labor market and 
the tradeoff between labor and leisure combined with the production function ultimately determines the level of output, wages would be listed fourth. And finally, exchange rates would be listed after inflation, since purchasing power parity is the ultimate determinate of exchange rates. Many VARs are sensitive to the ordering of the variables, and the assumptions of the model can shape the empirical results. As evidence of robustness of this empirical model, the ordering of the variables does not change the basic results. In several different orderings, the basic premise that inflation is cost push through wage and exchange rate effects holds.

Augmented Dickey-Fuller tests were performed on the variables and the test indicated that to create stationarity the variables should be differenced (Table 3). A reduced form vector autoregression is used as the primary model. A reduced form VAR for this model is better than a structural VAR for several reasons. The first is that a structural VAR is only as good as the strict identifying assumptions imposed on the matrix. To have a perfectly identified SVAR with six variables would require imposing up to 15 restrictions. ${ }^{11}$ Practitioners of SVARs can impose strict assumptions of causality on the variables, and oftentimes impose these restrictions for mathematical ease or for the sake of the identifying restrictions being triangular, which is a popular strategy. In other words, SVARs are only as good as the strict restrictions imposed on the variables, and these restrictions are prone to bias and the necessity for mathematical ease, which can produce preconceived results (Sims 1986). The authors of this paper see this as a weakness and use a standard VAR technique that allows all variables to be in a sense, causal, to effectively capture the interaction between a complex set of macroeconomic variables. Virtually every combination of variables listed above can be argued from one perspective or another to be causal or connected with another variable in some way. A reduced form VAR is the most realistic macroeconometric tool because of this issue. Cointegration was considered and the authors ran the models with a vector error correction model. The results were largely similar to what will be reported. The authors decided against addressing the cointegration issue because cointegration assumes long-run equilibriums between variables and adds an additional layer of variable transformation that can distort causal links. The VAR uses four lags as selected using the Akaike information criterion (AIC).

\footnotetext{
${ }^{11}$ To identify the structural model from an estimated VAR, it is necessary to impose $\left(n^{2}-n\right) / 2$ restrictions on the structural model (Enders 2004).
} 
Table 3 Augmented Dickey-Fuller tests

\begin{tabular}{lcc}
\hline Variable & In Levels & In 1st Differences \\
\hline lncpi (8 lags, trend) & -1.961 & $-3.209^{*}$ \\
lnER (8 lags) & -1.540 & $-3.584^{* * *}$ \\
lnwage (8 lags, trend) & -2.839 & $-4.607 * * *$ \\
Lnimportprices (lags 8, trend) & -2.440 & $-4.243^{* * *}$ \\
Lnoil (lags 8, trend) & -1.657 & $-4.591 * * *$ \\
LnTaylorRule (lags 8) & -1.610 & $-4.592^{* * *}$ \\
\hline
\end{tabular}

*** Indicates significance at the $99 \%$ level

** Indicates significance at the $95 \%$ level

\section{RESULTS}

The impulse response functions (IRF) for model 1 are listed in Figure 8, and variance decompositions (VD) for the CPI are listed in Table 4. IRFs and VDs show that the Taylor rule is not sufficient to explain inflation during the Great Moderation period. The IRF shows that an increase in the Taylor rule differential has an ambiguous effect on inflation. The IRF is negative for the first four quarters, which is the opposite of the expected result, and then goes positive after 12 periods. The VDs show that the amount of variation that the Taylor rule can explain is approximately 4.5 percent and this is after almost six quarters of data. From this result, it is fair to say that the Taylor rule has had an effect on inflation, but is directionally ambiguous. We can also say that the Taylor rule effect is significantly smaller compared to the other factors in the model.

Figure 8 Impulse response functions
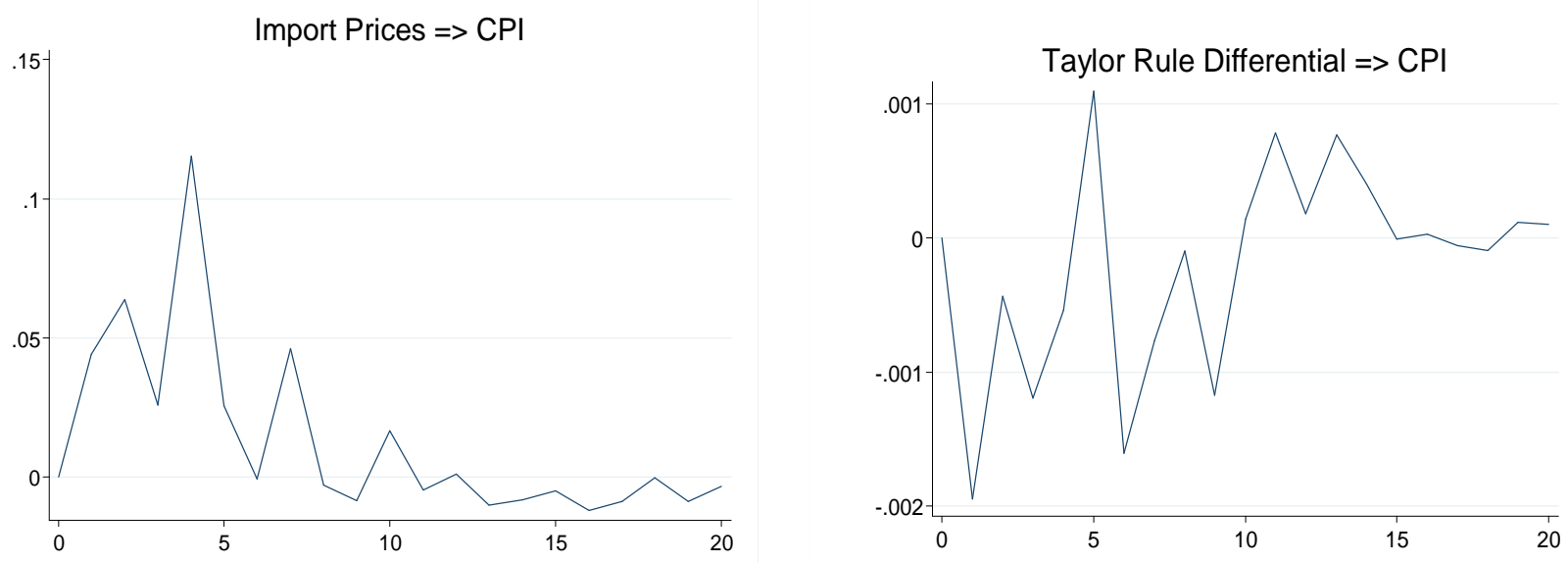

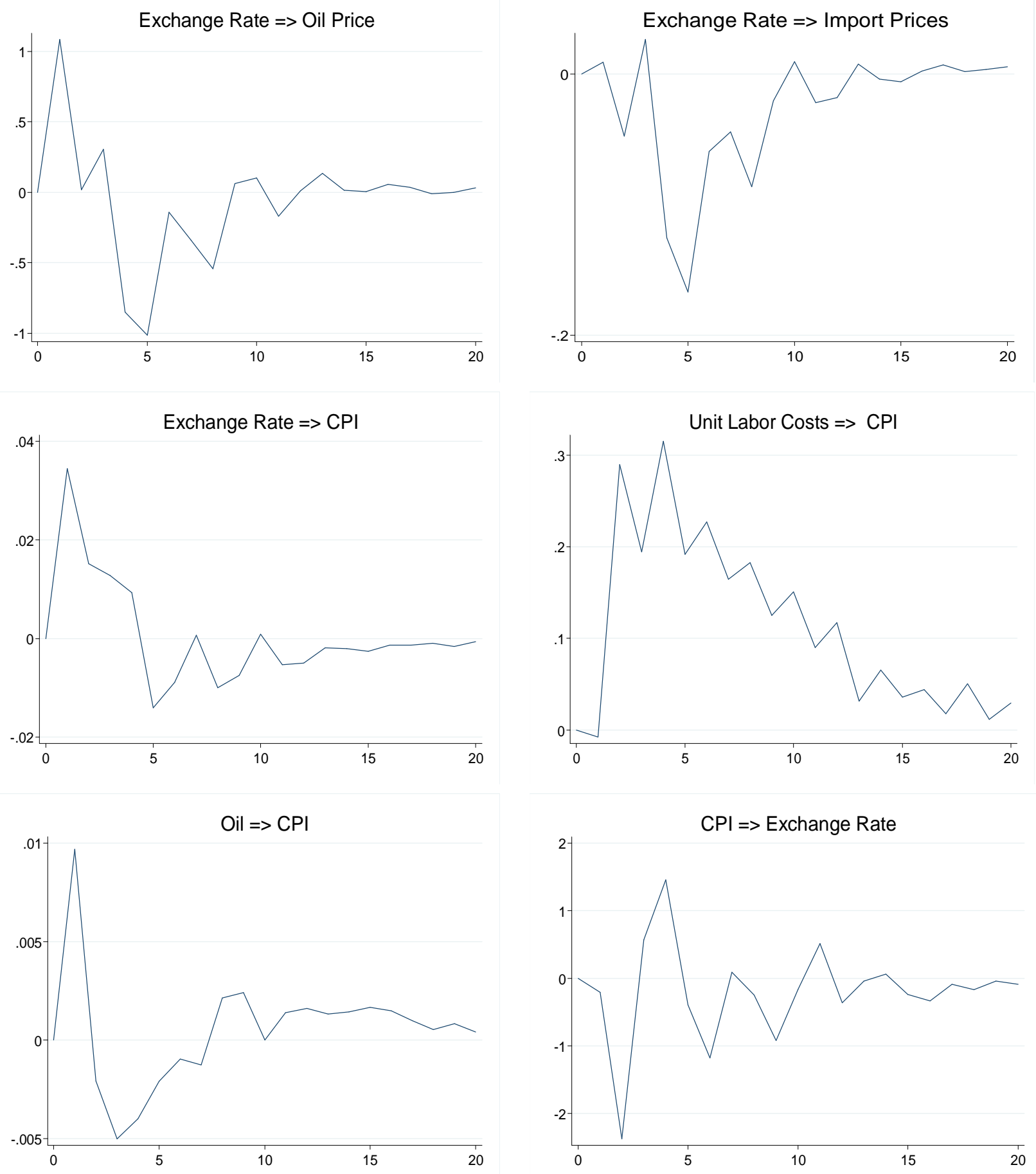


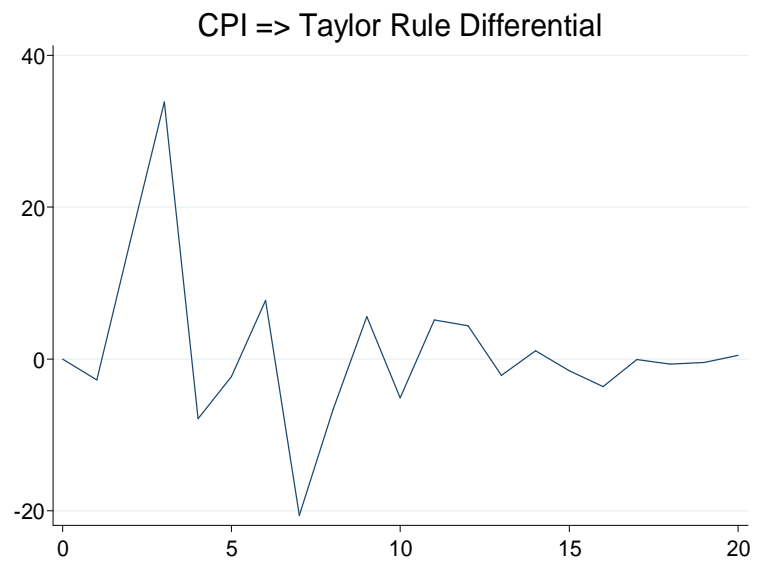

Table 4 Variance decomposition CPI

\begin{tabular}{|c|c|c|c|c|c|c|}
\hline $\begin{array}{l}\text { Variance } \\
\text { Decomposition of the CPI } \\
\text { (response) }\end{array}$ & & $\begin{array}{l}\text { Impulse } \\
\text { Variable }\end{array}$ & & & & \\
\hline Horizon & CPI & $\begin{array}{l}\text { Taylor } \\
\text { Rule }\end{array}$ & $\begin{array}{c}\text { Exchange } \\
\text { Rate }\end{array}$ & $\begin{array}{l}\text { Import } \\
\text { Prices }\end{array}$ & Oil Prices & Wages \\
\hline 1 & .3858 & .0056 & .0005 & .6019 & .0011 & .0049 \\
\hline 2 & .3047 & .0431 & .0219 & .5776 & .0484 & .0039 \\
\hline 3 & .2986 & .0427 & .0262 & .5590 & .0483 & .0249 \\
\hline 4 & .2936 & .0438 & .0323 & .5407 & .0530 & .0363 \\
\hline 6 & .2967 & .0449 & .0366 & .5062 & .0573 & .0580 \\
\hline 10 & .2830 & .0513 & .0388 & .4867 & .0579 & .0821 \\
\hline 20 & .2795 & .0523 & .0392 & .4763 & .0617 & .0907 \\
\hline
\end{tabular}

The exchange rate IRF shows that as the exchange rate increases, inflation increases for the first 4 quarters. After this initial effect, the increased exchange rate begins to reduce inflation. The aggregate effect over 20 quarters shows that an increase in the exchange rate reduces inflation. The reason for the initial increase in inflation due to a positive exchange rate shock is not entirely clear. It can be partially explained by J-curve effects, or the expected delay in exchange rate pass-through effects due to previous trade contracts. The VD shows that the exchange rate explains approximately 3 percent of the percentage contribution of innovations from the exchange rate to inflation. This does not mean the exchange rate is not important; it merely means that the chain of effects must be explained. Because this model also includes oil prices and import prices, the direct effect of the exchange rate is, in a sense, controlled for. The more important finding is that both oil prices and import prices respond directly to changes in the exchange rate. As the exchange rate appreciates, import prices fall and so do oil prices, although oil prices follow more precisely the pattern of the exchange rate over the first two 
quarters. The VDs support the causality of the transmission of import prices and oil prices through the exchange rate.

Import prices and oil complete the exchange rate story. Import prices are a result of both exchange rate effects and the cost of business overseas. In this model, we can see how exchange rates affect import prices, and how import prices affect inflation. The results for import prices show that they are vital to explaining falling inflation in the Great Moderation period. The IRF shows that a positive shock to import prices causes an increase in inflation. The exchange rate transmits this effect as a positive shock to import prices, which affects inflation. The other aspect to import prices, and arguably the more important, is that foreign labor costs fall, reducing the costs of imports. Although exchange rate effects on import prices are real, international competition and falling costs are a vitally important part to this model. International competition and globalization are hard to quantify in an empirical model of this kind. VDs for import prices show that import prices can explain almost 50 percent of the variation in inflation.

Oil prices are the next in the ordering. A positive shock to oil prices increases inflation the first three periods, but falls for periods 4 and 5, and then returns positive after that. The VD shows that oil can explain approximately 5 percent of the variation in inflation. In this model, oil is assumed to be endogenous in the sense that not only can supply and demand for oil affect oil prices, but the demand and supply decisions for oil are based on exchange rate effects. Adjusting for this shows that oil can have an impact on inflation, but it is not significant enough to explain the Great Moderation like some authors have claimed. And more specifically, when controlled for the endogenous nature of oil, the effect is smaller than the "good luck" literature suggests.

The IRF for unit labor costs shows that a positive increase in wages causes a clear positive increase in inflation. Wages have the second highest magnitude of impact after import prices. Earlier it was illustrated that wages have fallen during the Great Moderation period, which implies that as wages have fallen, inflation has fallen. The VD shows that wages explain up to 9 percent of the variation in inflation after the full 20 quarters. It is not surprising that wages take time to have their full effect on inflation due to the rigid nature of wages. This result can be interpreted as evidence for both a domestic attack on wages through the reduction in labor union membership, and increased international competition that has put competitive pressure on US wages. This was facilitated further by the exchange rate effects and international 
competition effects on the US manufacturing base, which was highly unionized and kept wages high.

The following can be summarized from the results:

1) Oil prices are not strong enough to explain the Great Moderation, contrary to the "good luck" or oil hypothesis.

2) Monetary policy as measured by a Taylor rule differential is not strong enough to explain the Great Moderation, contrary to the "good policy" literature.

3) Falling wages and falling import prices are the primary determinants of the great moderation. The US has benefited from reduced wages due to international competition, decreased labor bargaining, and a fall in exporting due to a combination of external competition and exchange rate effects. Import prices have fallen due to an appreciated exchange rate and lower international costs have pushed prices down.

\section{CONCLUSION}

Traditional explanations of the Great Moderation fall into three categories: good luck, good policy, and structural changes. This paper has tested both the good luck and good policy hypotheses in a Post-Keynesian markup model and determined that it is neither good policy nor good luck that caused the great inflation moderation. The Great Moderation was, in fact, a great wage and import price moderation that stabilized and pushed prices down. The implications of this study are important. First of all, monetary policy assuming a Wicksellian natural rate of interest, or what we call the Taylor rule, may not be the important policy tool that theorists have imagined it to be. Another implication is the role of good luck. Oil prices are important to the great inflation moderation, however the good luck literature does not understand the endogenous nature of oil prices and how they are related to the exchange rate. To lower oil prices and their role in inflation, one would need only to increase the value of the US dollar to push oil prices lower. This, of course, has other implications on different sectors of the economy which are beyond the scope of this paper. Another implication is that inflation has fallen at the cost of wages to workers. Inflation has in a large part fallen because workers have taken consistent real wage cuts, lowering the cost of business and reducing prices. And lastly, the great inflation moderation was mostly due to increased international competition and exchange rate effects lowering import prices. 


\section{REFERENCES}

Ahmed, S., A. Levin, and B. A. Wilson. 2004. "Recent US Macroeconomic Stability: Good Policies, Good Practices, or Good Luck?" The Review of Economics and Statistics, MIT Press 86(3): 824-32.

Arestis, P., G. Caporale, and A. Cipollini. 2002. "Does Inflation Targeting Affect the Trade-Off between Output Gap and Inflation Variability?" Manchester School, University of Manchester 70(4): 528-45.

Arestis, P. and M. Sawyer. 2008. "New Consensus Macroeconomics and Inflation Targeting: Keynesian Critique." Economia e Sociedade 17: 629-54.

- 2004. Re-examining Monetary and Fiscal Policy for the 21st Century. Cheltenham, UK: Edward Elgar Publishing.

Bezemer, D. J. 2009. “"No One Saw This Coming': Understanding Financial Crisis through Accounting Models." Unpublished.

Bernanke, B. S. 2004. "The Great Moderation.” Remarks at the meetings of the Eastern Economic Association. Washington, DC. February 20.

Blanchard, O. and J. Simon. 2001. "The Long and Large Decline in U.S. Output Volatility." Brookings Papers on Economic Activity 2001(1): 135-64

Chatterjee, S. 2002. "The Taylor Curve and the Unemployment-Inflation Tradeoff." Business Review, Federal Reserve Bank of Philadelphia Q3: 26-33.

Carlin, W. and D. Soskice. 2005. "The 3-Equation New Keynesian Model-A Graphical Exposition." The B.E. Journal of Macroeconomics 0(1): 13.

Clarida, R., J. Gali, and M. Gertler. 2000. "Monetary Policy Rules and Macroeconomic Stability: Evidence and Some Theory." The Quarterly Journal of Economics 115(1): $147-80$.

DeLong, J. B. 1997. “America's Peacetime Inflation: The 1970s.” In C. Romer and D. H. Romer (Eds.), Reducing Inflation: Motivation and Strategy. Chicago: University of Chicago Press for NBER.

Dueker, M. J. and A. M. Fischer. 2006. "Do Inflation Targeters Outperform Non-Targeters?" Saint Louis Federal Reserve Review 88(5): 431-50.

Enders, W. 2004. Applied Econometric Time Series. Hoboken: John Wiley. 
Galbriath, J. K. 1997. “Time to Ditch the NAIRU.” The Journal of Economic Perspectives 11(1): 93-108.

Grabel, I. 2003. "Ideology, Power and the Rise of Independent Monetary Institutions in Emerging Economies.” In J. Kirshner (Ed.), Monetary Orders: Ambiguous Economics, Ubiquitous Politics. Ithaca: Cornell University Press.

Godley, W. 1999. Seven Unsustainable Processes: Medium-Term Prospects and Policies for the United States and the World. Strategic Analysis. Annandale-on-Hudson, NY: Levy Economics Institute of Bard College. January.

Hamilton, J. D. and A. M. Herrera. 2004. "Comment: Oil Shocks and Aggregate Macroeconomic Behavior: The Role of Monetary Policy." Journal of Money, Credit and Banking 36(2): 265-86.

Harvey, J. 1991. “A Post Keynesian View of Exchange Rate Determination.” Journal of Post Keynesian Economics. 14(1): 61-71.

- 2006. "Post Keynesian versus Neoclassical Explanations of Exchange Rate Movements: A Short Look at the Long Run." Journal of Post Keynesian Economics. 28(2): 161-79.

Justiniano, A. and G. E. Primiceri. 2006. "The Time Varying Volatility of Macroeconomic Fluctuations.” NBER Working Papers 12022. Cambridge, MA: National Bureau of Economic Research.

Keen, S. 2006. Steve Keen's Monthly Debt Report November 2006. “The Recession We Can't Avoid?" Steve Keen's Debtwatch. Sydney. 1: 21.

- 2013. "A Monetary Minsky Model of the Great Moderation and the Great Recession." Journal of Economic Behavior \& Organization 86: 221-35.

Kahn, J. A., M. M. McConnell, and G. Perez-Quiros. 2002. "On the Causes of the Increased Stability of the US Economy." Federal Reserve Bank of New York Economic Policy Review (May): 183-202.

Keynes, J. M. 1936. The General Theory of Employment, Interest and Money. New York: Harcourt, Brace.

Kim, C-J., C. Nelson, and J. Piger. 2003. "The Less Volatile US Economy: A Bayesian Investigation of Timing Breadth, and Potential Explanations." Working Paper No 2001016. St Louis, MO: Federal Reserve Bank of St. Louis.

Lavoie, M. 1992. Foundations of Post-Keynesian Economic Analysis. Aldershot, Hants, England: E. Elgar.

Lucas, R. E. 1972. "Expectations and the Neutrality of Money." Journal of Economic Theory 4(2): 102-24. 
—. 2003. "Macroeconomic Priorities." American Economic Review 93(1): 1-14.

Meltzer, A. H. 2005. "Origins of the Great Inflation." Federal Reserve Bank of St. Louis Review 87(2): 145-76.

Friedman, M. 1968. “The Role of Monetary Policy.” The American Economic Review 58(1): 117.

McConnell, M. M. and G. Perez-Quiros. 2000. "Output Fluctuations in the United States: What Has Changed since the Early 1980s?" American Economic Review, American Economic Association 90(5): 1464-76.

Minsky, H. P. 1986. Stabilizing an Unstable Economy. New Haven, CT: Yale University Press.

Meyer, L. H. 2001. "Does Money Matter?” Review-Federal Reserve Bank of Saint Louis 83(5): $1-16$.

Palley, T. I. 2002. "Economic Contradictions Coming Home to Roost? Does the US Economy Face a Long-Term Aggregate Demand Generation Problem?" Journal of Post Keynesian Economics 25(1): 9-32.

Romer, C. and D. Romer. 2002. "The Evolution of Economic Understanding and Postwar Stabilization Policy.” NBER Working Papers 9274. Cambridge, MA: National Bureau of Economic Research.

Smithin, J. N. 2003. Controversies in Monetary Economics. Cheltenham, UK: Edward Elgar.

Sims, C. 1986. “Are Forecasting Models Usable for Policy Analysis?” Federal Reserve Bank of Minneapolis Quarterly Review 10(1): 2-16.

Stock, J. and M. W. Watson. 2003. "Understanding Changes in International Business Cycle Dynamics." NBER Working Papers 9859. Cambridge, MA: National Bureau of Economic Research.

Taylor, J. B. 1993. "Discretion versus Policy Rules in Practice." Carnegie-Rochester Conference Series on Public Policy 39(1): 195-214.

— 1999. "The Robustness and Efficiency of Monetary Policy Rules as Guidelines for Interest Rate Setting by the European Central Bank.” Journal of Monetary Economics 43(3): 655-79.

— 1979. "Estimation and Control of a Macroeconomic Model with Rational Expectations." Econometrica: Journal of the Econometric Society 47(5): 1267-86.

- 2012. First Principles: Five Keys to Restoring America's Prosperity. New York, NY: W.W. Norton \& Company. 
Taylor, L. 2004. Reconstructing Macroeconomics. Cambridge: Harvard University Press. Wicksell, K. 1898. Interest and Prices. London: Macmillan. 